\title{
ANALISIS STRATEGI PENETAPAN HARGA TERHADAP KEPUTUSAN KONSUMEN MENGGUNAKAN JASA OJEK ONLINE PT GO-JEK INDONESIA
}

\author{
Oleh : \\ Ai Annisaa Utami ${ }^{1}$ \\ Zahrudin ${ }^{2}$ \\ Sarah Ramadhanti ${ }^{3}$ \\ Program Studi Pendidikan Ekonomi \\ Fakultas Ilmu Pendidikan dan Pengetahuan Sosial \\ Universitas Indraprasta PGRI 1,2,3 \\ Email : \\ aiannisaa87@gmail.com ${ }^{1}$
}

\begin{abstract}
ABSTRAK
Penelitian ini bertujuan untuk mengetahui strategi penetapan harga yang digunakan oleh PT. Go-Jek Indonesia terhadap keputusan konsumen menggunakan jasa ojek online tersebut. Metode yang digunakan dalam penelitian adalah kualitatif. Penelitian ini menggunakan purposive sampling dan snowball sampling. Populasi dalam penelitian ini terdiri dari social situation yang diwakili oleh driver ojek online, ojek konvensional, dan pengguna ojek online. Berdasarkan hasil penelitian dapat ditarik kesimpulan bahwa strategi penetapan harga yang dilakukan Go-Jek yaitu strategi memposisikan layanan jasa melalui harga yang diberikan Go-jek. Go-Jek memposisikan layanan jasa melalui harga karena ingin layanan jasa yang diciptakan menarik perhatian konsumen dan juga berbagai layanan yang diberikan Go-Jek seperti jasa antar makanan. antar barang, taksi online, dan lain-lain telah sesuai dengan kebutuhan konsumen saat ini
\end{abstract}

Kata Kunci : Strategi Penetapan Harga. Keputusan Konsumen

\section{A. PENDAHULUAN}

Perusahaan di bidang jasa saat ini sedang berkembang dengan pesat, tidak terkecuali perusahaan jasa yang menggunakan teknologi informasi berbasis online. Salah satu perkembangan teknologi saat ini terdapat pada layanan jasa ojek online. Walaupun keberadaan transportasi ini sudah ada sejak dulu, tetapi menjadi sangat fenomenal ketika digabungkan dengan teknologi dan menjelma menjadi transportasi berbasis online. Salah satu transportasi online yang dikenal masyarakat saat ini adalah 
Go-Jek. Bermula di tahun 2010 sebagai perusahaan transportasi roda dua melalui panggilan telepon, Go-Jek kini telah tumbuh menjadi aplikasi terdepan yang menyediakan berbagai layanan lengkap mulai dari transportasi, logistik, pembayaran, layanan antar makanan, dan berbagai layanan lainnya.

Go-Jek Indonesia merupakan penyedia jasa layanan ojek profesional yang menawarkan faktor kecepatan, keamanan, dan kenyamanan bagi para pelanggannya. Aplikasi bisnis ini memang sangat memudahkan seluruh masyarakat untuk memenuhi kegiatan dan kebutuhan sehari-hari. Go-Jek selalu menghadirkan inovasi baru mulai dari macam-macam layanan yang ditawarkan hingga tampilan desain aplikasi yang selalu update. Pemasaran mempunyai peranan yang penting bagi perusahaan jasa karena pemasaran menyangkut berbagai aspek kehidupan masyarakat, termasuk bidang ekonomi dan sosial karena kegiatan pemasaran menyangkut masalah mengalirnya sesuatu yang dihasilkan produsen ke konsumen. Teknologi pun berpengaruh bagi ke dalam bidang pemasaran yang membuat kemudahan bagi perusahaan maupun konsumen Berikut data yang menunjukkan perbandingan pengguna aplikasi jasa ojek online di Indonesia pada tahun 2016.

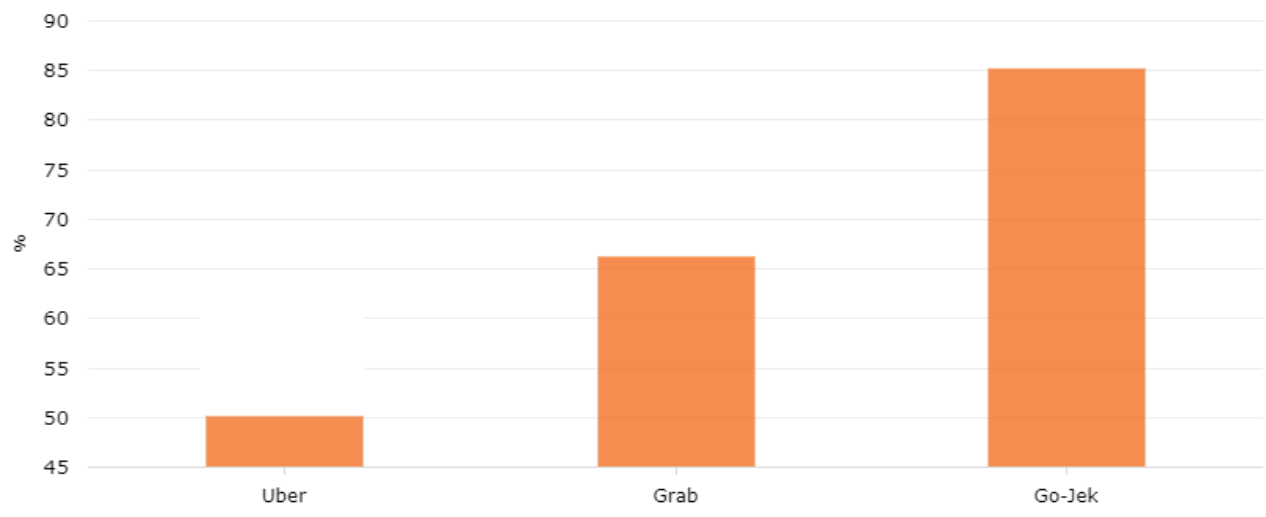

Sumber :Databoks. katadata

Gambar 1

Grafik Pengguna Transportasi Ojek Online di Indonesia

Gambar diatas menunjukkan banyaknya pengguna aplikasi transportasi online yang paling banyak digunakan oleh masyarakat di Indonesia. Ini berdasarkan dari hasil survei DailySocial.Id yang menunjukkan bahwa sebanyak 85,22\% responden telah menggunakan layanan transportasi yang didirikan PT. Go-Jek Indonesia. Sementara responden yang menggunakan Grab hanya 66,24\% Pengguna aplikasi GoJek mengungguli pada bidang jasa ojek online. Grab Bike

Perusahaan jasa harus melakukan strategi yang tepat dalam memengaruhi konsumen agar konsumen selalu yakin dan tidak merubah keputusan dalam 
menggunakan jasa yang lain seperti persaingan tarif antar jasa ojek online yang selalu memberikan penawaran potongan harga mengakitbatkan perilaku konsumen yang dapat berubah secara tidak langsung perusahaan akan mengalami penurunan pendapatan dalam jangka pendek. Jika perusahaan jasa tidak mempunyai nilai jual yang dimiliki perusahaan dan inovasi yang baru, maka dalam jangka panjang perusahaan akan mengalami kekalahan dan kerugian hingga kebangkrutan ditengah persaingan untuk memengaruhi keputusan konsumen. Yang terpenting dalam perusahaan jasa pemecahan terhadap persaingan dengan mengembangkan produk jasa dan citra yang berbeda. Perusahaan jasa dapat menambah beberapa ciri inovatif untuk memungkinkan poduk jasa yang ditawarkan berbeda. Salah satu tantangan yang dihadapi perusahaan ialah bahwa sebagian besar inovasi jasa mudah ditiru. Hanya sedikit perusahaan yang mampu mencegah peniruan jasa ini dalam jangka panjang. Dengan begitu, perusahaan jasa saat ini harus memperoleh keunggulan sementara terhadap pesaingnya.

Bagi perusahaan jasa pentingnya perilaku konsumen sangat berpengaruh terhadap penjualan kelangsungan suatu perusahaan.Khususnya dalam manajemen pemasarannya untuk selalu berusaha memengaruhi pengenalan bentuk jasa yang ditawarkan terhadap konsumen. Kebijakan permasaran sangat ditentukan oleh kemampuan perusahaan dalam mengidentifikasi karakteristik konsumen, termasuk dalam hal sikap, perilaku dan pengambilan keputusan konsumen. Bagi pemasar, perilaku konsumenmemberikan informasi penting bagi penentuan strategi pemasaran. Dengan memahami perilaku konsumen, pemasar dapat menentukan strategi pemasaran yang tepat. Pemasaran memberi perhatian pada hubungan timbal balik yang dinamis antara produk produk dan jasa-jasa perusahaan, keinginan dan kebutuhan konsumen dan kegiatan para pesaing.

Keberhasilan sebuah pemasaran perusahaan jasa tergantung pada tingkat keselarasan antara lingkungan pasar dan kemampuan internal perusahaan tersebut. Jika unsur-unsur bauran pemasaran tidak selaras dengan kemampuan internal perusahaan, kualitas jasa yang diberikandengan permintaan konsumen tidak akan maksimal. Oleh karena itu, sudah selayaknya untuk memikirkan kembali bauran pemasaran dalam konteks jasa.Hal ini menuntut perusahaan untuk mempertimbangkan konsumen sebagai salah satu faktor terpenting dalam pasar, karena dengan memperhatikan kebutuhan dan keinginan konsumen, perusahaan dapat memenangkan persaingan pasar. Jika unsur bauran pemasaran tersebut telah dipertimbangkan oleh perusahaan jasa, maka dapat memberikan manfaat bagi perusahaan salah satunya konsumen akan membuat keputusan dalam penggunaan jasa

Keputusan konsumen menggunakan Go-Jek sebagai jasa ojek online salah satunya pemasaran yang PT. Go-Jek Indonesia dalam menentukan tarifnya yang relatif murah dan sangat jauh perbedaan tarifnya dengan ojek konvensional atau ojek pangkalan. Harga memainkan peran yang sangat penting dalam bauran pemasaran jasa, karena penetapan harga memberikan penghasilan bagi perusahaan sedangkan, unsur lainnya dalam bauran pemasaran menggunakan biaya perusahaan. Demikian 
sekarang ini bagi perusahaan jasa harus lebih teliti dalam masalah penetapan harga dengan baik. Kegiatan penentuan harga juga penting dalam menentukan seberapa jauh sebuah layanan jasa dinilai oleh konsumen dan proses pembangunan citra. Penentuan harga juga memberikan persepsi tertentu dalam hal kualitas. Menurut (Payne, 2002) Keputusan-keputusan penetapan harga mempunyai dampak pada seluruh bagian saluran pemasaran, pemasok, pesaing dan pelanggan. Lebih jauh penetapan harga memengaruhi persepsi pembeli jasa yang ditawarkan.

Alasan ekonomis akan menunjukkan bahwa harga yang rendah atau harga yang selalu berkompetisi merupakan salah satu pemicu penting untuk meningkatkan kinerja pemasaran, tetapi alas an psikologis dapat menunjukkan bahwa harga justru merupakan idikator kualitas dan karena itu dirancang sebagai salah satu instrumen penjualan sekaligus sebagai instrumen kompetisi yang menentukan. Menurut (Kotler P. a., 2009) menyatakan bahwa "Kebijakan harga adalah suatu alat atau cara yang dipergunakan perusahaan untuk menetapkan harga dan bisa memengaruhi konsumen dalam melakukan pembelian terhadap barang yang ditawarkan oleh perusahaan dan berapa banyak pendapatan yang diperoleh."Pada umumnya harga ditetapkan melalui negosiasi antara pembeli dan penjual.Tawar menawar masih merupakan permainan di beberapa wilayah.Menetapkan satu harga untuk semua pembeli merupakan gagasan yang relatif modern yang muncul bersama perkembangan eceran berskala besar.

Berdasarkan pendapat tersebut kebijakan harga merupakan alat, pegangan yang dipakai oleh perusahaan untuk menentukan harga dalam jangka waktu tertentu dan menetapkan harga jual perusahaan untuk memengaruhi konsumen dalam melakukan pembelian terhadap barang yang ditawarkan. Beberapa penelitian menunjukkan bahwa konsumen akan menjadi loyal pada merek-merek berkualitas tinggi jika produk yang ditawarkan dengan harga yang wajar. Dalam hal ini dapat diambil kesimpulan bahwa kosnumen akan tetap loyal pada merek-merek yang berkualitas, bergengsi dan eksklusif apabila ditawarkan dengan harga yang wajar. Selain itu, terdapat tipe konsumen yang loyal pada produk dengan harga yang murah. Keputusan-keputusan konsumen harga untuk jasa melibatkan persaingan perusahaan jasa seperti Go-Jek dan Grab bike selalu bersaing dalam penetapan harga diskon agar menarik keputusan untuk menggunakan jasanya.Penetapan harga para pesaing merupakan hal yang penting bagi perusahaan.Perusahaan jasa harus berusaha mematok harga pesaing untuk menentukan biaya, harga dan profitabilitas perusahaan.Harus melakukan perbandingan harga dan kualitas terhadap masingmasing pesaing

\section{B. KAJIAN PUSTAKA}

\section{Keputusan Pembelian}

Menurut (Kotler, 2005), "Keputusan pembelian adalah suatu tahap dimana konsumen telah memiliki pilihan dan siap untuk melakukan pembelian atau pertukaran antara uang dan janji untuk membayar dengan hak kepemilikan atau penggunaan suatu barang atau jasa". (Kotler, 2005) juga menjelaskan yang dimaksud 
dengan keputusan pembelian adalah suatu proses penyelesaian masalah yang terdiri dari menganalisa atau pengenalan kebutuhan dan keinginan hingga perilaku setelah pembelian. Menurut (Olson, 2000) "keputusan pembelian adalah proses mengkombinasikan pengetahuan untuk mengevaluasi dua atau lebih perilaku alternatif dan memilih salah satu diantaranya."

Menurut (Kanuk, 2004), keputusan pembelian adalah pemilihan dari dua atau lebih alternatif pilihan keputusan pembelian, artinya bahwa seseorang dapat membuat keputusan, harus tersedia beberapa alternatif pilihan.Keputusan untuk membeli dapat mengarah pada bagaimana proses dalam pengambilan keputusan tersebut itu dilakukan. (Setiadi, 2003) menuturkan pengambilan keputusan yang diambil oleh konsumen dapat disebut sebagai pemecahan masalah. Dalam proses pengambilan keputusan, konsumen memiliki sasaran atau perilaku mana yang ingin dilakukan untuk mencapai sasaran tersebut. Dengan demikian, hal ini dapat membantu memecahkan masalahnya.Selanjutnya dijelaskan pemecahan masalah merupakan suatu aliran timbal balik yang berkesinambungan diantara faktor lingkungan, proses kognitif dan afektif serta tindakan perilaku.Pada tahap pertama merupakan pemahaman adanya masalah.Selanjutnya terjadi evaluasi terhadap alternatif yang ada dan tindakan yang paling sesuai dipilih. Pada tahap selanjutnya, pembelian dinyatakan dalam tindakan yang pada akhirnya barang yang telah dipilih atau ditunjuk akan digunakan dan konsumen akan melakukan evaluasi ulang mengenai keputusan yang telah diambilnya.

(Pranoto, 2008) juga menjelaskan perilaku pengambilan keputusan oleh konsumen untuk melakukan pembelian produk atau jasa diawali dengan adanya kesadaran atas pemenuhan kebutuhan atau keinginan dan menyadari adanya masalah selanjutnya, maka konsumen akan melakukan beberapa tahap yang pada akhirnya sampai pada tahap evaluasi pasca pembelian. Menurut (Assauri, 2004) Keputusan pembelian merupakan suatu proses pengambilan keputusan akan pembelian yang mencakup penentuan apa yang akan dibeli atau tidak melakukan pembelian dan keputusan itu diperoleh dari kegiatan-kegiatan sebelumnya.

Dari beberapa pengertian pengambilan keputusan yang telah dipaparkan diatas, maka dapat diambil kesimpulan bahwa keputusan pembelian adalah suatu proses pengambilan keputusan akan pembelian yang akan menentukan dibeli atau tidaknya pembelian tersebut yang diawali dengan kesadaran atas pemenuhan atau keinginan. Setelah itu konsumen dapat melakukan evaluasi pilihan dan kemudian dapat menentukan sikap yang akan diambil selanjutnya

\section{Faktor-faktor yang Memengaruhi Keputusan Pembelian}

(Kotler P. a., 2009) menyatakan bahwa perilaku pembelian konsumen dipengaruhi oleh faktor- faktor berikut :

1) Faktor budaya 
Faktor-faktor budaya mempunyai pengaruh yang paling luas dan paling dalam.Budaya, sub-budaya, dan kelas sosial sangat penting bagi perilaku pembelian.Budaya merupakan penentu keinginan dan perilaku yang paling dasar. Sub budaya mencakup kebangsaan,agama, kelompok ras, dan wilayah geografis. Sedangkan kelas sosial adalah pembagian masyarakat yang relatif homogen dan permanen, yang tersusun secara hirarkis dan yang para anggotanya menganut nilai, minat, dan perilaku yang serupa. Kelas sosial tidak hanya mencerminkan penghasilan, tetapi juga indikator lain seperti pekerjaan, pendidikan, dan wilayah tempat tinggal.

2) Faktor sosial

Selain faktor budaya, perilaku konsumen dipengaruhi oleh faktor-faktor sosial seperti kelompok acuan, keluarga, serta peran dan status sosial masyarakat.

a) Kelompok Acuan

Kelompok acuan seseorang terdiri atas semua kelompok di sekitar individu yang mempunyai pengaruh baik langsung maupun tidak langsung terhadap perilaku individu tersebut. Kelompok acuan memengaruhi pendirian dan konsep pribadi seseorang karena individu biasanya berhasrat untuk berperilaku sama dengan kelompok acuan tersebut. Keluarga sendiri biasanya menjadi sumber orientasi dalam perilaku. Anak akan cenderung berperilaku sama dengan orang tua saat mereka melihat perilaku orang tua mereka mendatangkan manfaat atau keuntungan.

b) Peran dan status dalam masyarakat

Peranan adalah kegiatan yang diharapkan untuk dilakukan mengacu pada orang-orang di sekellilingnya. Sedang status adalah pengakuan umum masyarakat sesuai dengan peran yang dijalankan. Setiap individu dan status yangdisandangnya akan memengaruhi perilakunya.

3) Faktor pribadi

Keputusan pembeli juga dipengaruhi oleh karakteristik pribadi. Karakteristik tersebut meliputi usia dan tahap siklus hidup, pekerjaan, keadaan ekonomi, gaya hidup, serta kepribadian dan konsep-diri pembeli.

a) Usia dan Tahap Siklus Hidup

Individu dalam membeli barang atau jasa biasanya disesuaikan dengan perubahan usia mereka. Pola konsumsi yang terbentuk juga berbeda antara individu-individu yang usianya berbeda.

b) Pekerjaan Pekerjaan

Individu tentunya ikut memengaruhi perilaku pembelian individu. Penghasilan yang mereka peroleh dari pekerjaannya itulah yang menjadi determinan penting dalam perilaku pembelian mereka.

c) Gaya Hidup.

Gaya hidup merupakan pola kehidupan seseorang sebagaimana tercermin dalam aktivitas, minat, dan opininya. Gaya hidup akan sangat memengaruhi pola tindakan dan perilaku individu . 
d) Kepribadian

Kepribadian adalah karakteristik psikologi yang berbeda dari seseorang yang menyebabkan tanggapan yang relatif konsisten dan tetap terhadap lingkungannya .

4) Faktor psikologis

Pilihan pembelian seseorang dipengaruhi oleh empat faktor psikologi utama. Faktor-faktor tersebut terdiri dari motivasi, persepsi, pembelajaran, serta keyakinan dan sikap. Kebutuhan akan menjadi motif jika didorong hingga mencapai tahap intensitas yang memadai. Motif adalah kebutuhan yang memadai untuk mendorong seseorang bertindak. Persepsi adalah proses yang digunakan oleh individu untuk memilih, mengorganisasi, dan menginterpretasi masukan informasi guna menciptakan gambaran dunia yang memiliki arti. Persepsi dapat sangat beragam antara individu satu dengan yang lain yang mengalami realitas yang sama.

a) Motivasi

Motivasi adalah kebutuhan yang memadai untuk mendorongseseorangbertindak. Seseorang memiliki banyak kebutuhan pada waktu tertentu. Beberapa kebutuhan bersifat biogenis: kebutuhan tersebut muncul dari tekanan biologis seperti lapar, haus, tidak nyaman. Sedangkan kebutuhan yang lain bersifat psikogenis: kebutuhan tersebut muncul dari tekanan psikologis seperti kebutuhan akan pengakuan, penghargaan, atau rasa keanggotaan kelompok .

b) Persepsi

Disamping motivasi mendasari seseorang untuk melakukan keputusan pembelian maka akan dipengaruhi juga oleh persepsinya terhadap apa yang diinginkan. Konsumen akan menampakkan perilakunya setelah melakukan persepsi terhadap keputusan apa yang akan diambil dalam membeli suatu produk .

c) Pembelajaran

Pembelajaran adalah suatu proses, yang selalu berkembang dan berubah sebagai hasil dari informasi terbaru yang diterima (mungkin didapatkan dari membaca, diskusi, observasi, berpikir) atau dari pengalaman sesungguhnya, baik informasi terbaru yang diterima maupun pengalaman pribadi bertindak sebagai feedback bagi individu dan menyediakan dasar bagi perilaku masa depan dalam situasi yang sama .

d) Keyakinan dan Sikap

Keyakinan adalah pemikiran deskriptif bahwa seseorang mempercayai sesuatu. dapat didasarkan pada pengetahuan asli, opini, dan iman. Sedangkan sikap adalah evaluasi, perasaan suka atau tidak suka, dan kecenderungan yang relatif konsisten dari seseorang pada sebuah obyek atau ide .

Dari uraian diatas dapat disimpulkan bahwa pengaruh dari faktor-faktor tersebut tidak dapat dikendalikan oleh pemasar akan tetapi faktor-faktor tersebutdapat 
berguna dalam memahami konsumen oleh karena itu sebuah perusahaan perlu menyesuaikan produk mereka dengan sikap konsumen yang sudah ada.

\section{Tahap - tahap Proses Pengambilan Keputusan Pembelian}

Menurut (Kotler P. a., 2009) tahapan dalam proses pengambilan keputusan pembelian terdiri dari lima tahap, yaitu:

1) Pengenalan masalah yaitu proses pembelian dimulai ketika pembeli mengenali masalah atau kebutuhan. Kebutuhan tersebut dapat dicetuskan oleh rangsangan internal atau eksternal. Para pemasar perlu mengidentifikasi keadaan yang memicu kebutuhan tertentu. Dengan mengumpulkan informasi dari sejumlah konsumen, para pemasar dapat mengidentifikasikan rangsangan yang paling sering membangkitkan minat akan kategori yang mampu memicu minat konsumen.

2) Pencarian informasi yaitu konsumen yang terangsang kebutuhannya akan terdorong untuk mencari informasi yang lebih banyak. Kita dapat membaginya kedalam dua level rangsangan. Situasi pencarian informasi yang lebih ringan dinamakan penguatan perhatian. Pada level itu orang hanya sekadar lebih peka terhadap informasi produk. Pada level selanjutnya, orang itu mungkin masuk ke pencarian informasi secaraaktif: mencari bahan bacaan, menelepon teman, dan mengunjungi toko untuk mempelajari produk tertentu. Sumber informasi konsumen digolongkan kedalam empat kelompok: a) Sumber pribadi : keluarga, teman, tetangga, kenalan. b) Sumber komersial : iklan, wiraniaga, penyalur, kemasan,pajangan di toko c) Sumber publik: media massa, organisasi penentu peringkat konsumen. d) Sumber pengalaman: pengenalan, pengkajian, dan pemakaian produk.

3) Evaluasi alternatif

Terdapat beberapa proses evaluasi keputusan, dan model yang terbaru memandang proses evaluasi konsumen sebagai proses yang berorientasi kognitif, yaitu model tersebut menganggap konsumen membentuk penilaian atas produk dengan sangat sadar dan rasional. Beberapa konsep dasar akan membantu kita memahami proses evaluasi konsumen: pertama, konsumen berusaha memenuhi kebutuhan. Kedua, konsumen memandang masingmasing produk sebagai sekumpulan atribut dengan kemampuan yang berbedabeda dalam memberikan manfaat yang digunakan untuk memuaskan kebutuhan itu. Para konsumen memiliki sikap yang berbeda-beda dalam memandang berbagai atribut yang dianggap relevan dan penting. Mereka akan memberikan perhatian terbesar pada atributyang memberikan manfaat yang dicarinya.

4) Keputusan pembelian

Dalam tahap evaluasi, para konsumen membentuk preferensi atas merekmerek yang ada di dalam kumpulan pilihan. Konsumen tersebut juga dapat membentuk niat untuk membeli merek yang paling disukai. Terdapat dua 
faktor yang memengaruhi keputusan pembelian konsumen yaitu, faktor pertama adalah sikap orang lain. Sejauh mana sikap orang lain mengurangi alternatif yang disukai seseorang akan bergantung pada dua hal :

a) Intensitas sikap negatif orang lain terhadap alternatif yang disukai konsumen dan motivasi konsumen untuk menuruti keinginan orang lain. Semakin gencar sikap negatif orang lain dan semakin dekat orang lain tersebut dengan konsumen, konsumen akan semakin mengubah niat pembeliannya.

b) Faktor kedua adalah faktor sutuasi yang tidak terantisipasi yang dapat muncul dan mengubah niat pembelian, seperti : harga yang diharapkan, dan manfaat yang diharapkan.

5) Perilaku pasca pembelian

Setelah melakukan pembelian produk, konsumen akanmengalami level kepuasan atau ketidakpuasan. Tugas pemasartidak berakhir saat produk dibeli, melainkan berlanjut hinggaperiode pascapembelian. Pemasar harus memantau kepuasanpascapembelian, tindakan pascapembelian, dan pemakaian produkpascapembelian.

Tahap-tahap proses pengambilan keputusan pembelian di atasmenunjukkan bahwa para konsumen harus melalui seluruh urutan tahapketika membeli produk, namun tidak selalu begitu. Para konsumen dapatmelewati atau membalik beberapa tahap.

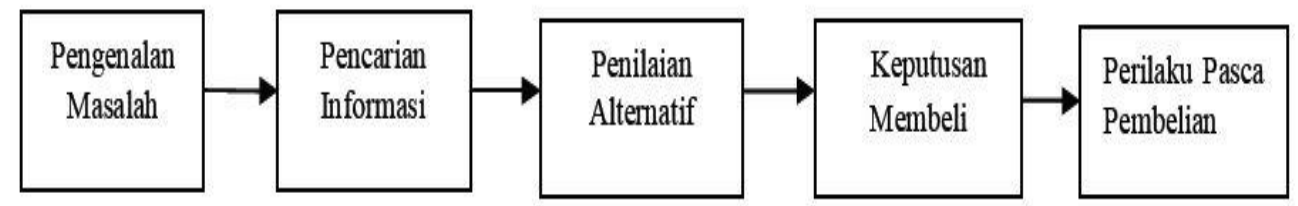

Sumber : (Kotler, 2008:257)

Gambar 2.

Tahap-tahap Proses Pengambilan Keputusan

Keputusan konsumen timbul karena adanya penilaian objektif atau karena dorongan emosi. Keputusan untuk bertindak adalah hasil dari serangkaian aktivitas dan rangsangan mental emosional. Proses untuk menganalisa, merasakan dan memutuskan, pada dasarnya adalah sama seperti seorang individu dalam memecahkan banyak permasalahannya. 


\section{Strategi Penetapan Harga}

Pengertian Harga Menurut (Swastha, 2009) harga adalah jumlah uang (ditambah beberapa barang kalau mungkin) yang dibutuhkan untuk mendapatkan sejumlah kombinasi dari barang beserta pelayannya. Biasanya para pemasar menetapkan harga untuk kombinasi antara:

1) Barang atau jasa spesifik yang menjadi objek transaksi

2) Sejumlah layanan pelengkap

3) Manfaat memuaskan kebutuhan yang diberikan produk bersangkutan.

Dari pendapat diatas dapat disimpulkan bahwa harga merupakan bagian penting dari bauran pemasaran yang digunakan untuk memperoleh barang atau jasa serta memanfaatkannya dengan sejumlah uang tertentu.Penetapan harga selalu menjadi masalah bagi setiap perusahaan, karena penetapan harga ini bukanlah kekuasaaan atau kewenangan yang mutlak dari seorang pengusaha.Dengan penetapan harga perusahaan dapat menciptakan hasil penerimaan penjualan dari produk yang dihasilkan dan dipasarkannya. Peranan penetapan harga akan menjadi sangat penting terutama pada keadaan persaingan yang semakin tajam dan perkembangan permintaan yang terbatas.

Peranan harga sangat penting terutama untuk menjaga dan meningkatkan posisi perusahaan di pasar, disamping untuk meningkatkan penjualan dan keuntungan perusahaan.Adapun tujuan penetapan harga menurut (Rahman, 2010) yaitu 1)Tujuan berorientasi pendapatan hampir sebagian besar bisnis berorientasi pada pendapatan, hanya perusahaan nirlaba atau pelayanan jasa publik yang biasanya berfokus pada titik impas. 2) Tujuan berorientasi kapasitas beberapa sektor bisnis biasanya menyelaraskan antara permintaan dan penawaran dan memanfaatkan kapasitas produksi maksimal. 3) Tujuan berorientasi pelanggan biasanya penetapan harga yang diberikan cukup representatif dengan segala tipe pelanggan, segmen pasar, dan perbedaan daya beli. Bisa dengan menggunakan sistem diskon, bonus, dan lain-lain.

Penetapan harga merupakan keputusan krisis yang menunjang keberhasilan operasi organisasi profit maupun non-profit.Harga merupakan satu-satunya unsur bauran pemasaran yang memberikan pendapatan bagi organisasi.Namun, keputusan mengenai harga (dalam konteks pemasaran jasa) tidak mudah dilakukan. Di satu sisi, harga yang terlalu mahal bias meningkatkan laba jangka pendek. Akan tetapi, di sisi lain akan sulit dijangkau konsumen dan sukarbersaing dengan competitor.

Dalam kasus tertentu, harga yang terlampau mahal dapat diprotes lembaga konsumen bahkan mengundang campur tangan pemerintah untuk menurunkannya. Selain itu, margin laba yang besar cenderung menarik para pesaing untuk masuk ke industri yang sama. Namun, bila harga terlalu murah, pangsa pasar bisa melonjak, margin kontribusi dan laba bersih yang diperoleh akan berkurang. Selain itu, sebagian konsumen bisa saja mempersepsikan kualitasnya jelek. 


\section{Strategi Penetapan Harga Jasa}

Menurut (Tjiptono, 2014) menyatakan bahwa selama ini banyak terjadi kekeliruan fundamental dalam praktik penetapan harga jasa dikarenakan para pemasar jasa mengabaikan tantangan khusus dalam menetapkan harga produk yang sifatnya intangible. Prinsip utama dalam strategi penetapan harga jasa adalah mengaitkan secara jelas harga yang dibayarkan pelanggan dengan nilai yang mereka terima dari konsumsi jasa perusahaan. Strategi-strategi ini dirangkum dalam tiga kelompok utama yan saling berkaitan : satisfaction-based pricing, relationship pricing dan efficienty pricing.

\section{1) Satisfaction-Based Pricing}

Dalam pembelian produk, baik jasa maupun produk fisik, berbagai macam ketidakpastian biasanya muncul misalnya risiko finansial, risiko sosial, risiko psikologis, risiko keamanan, dan lainnya.Tujuan utama satisfaction-based pricing adalah untuk mengurangi ketidakpastian yang dirasakan pelanggan. Penyedia jasa mengupayakan hal ini beberapa cara :

a. Garansi jasa (service guarantees)

Garansi jasa secara eksplisit bias berperan sebagai jaminan yang sangat positif bagi pelanggan. Sekalipun pada akhirnya pelanggan tidak puas terhadap jasa yang dibelinya, keberadaan garansi bias memberikan semacam kompensasi atas kekecewaan yang dirasakan.Apabila diterapkan secara benar, garansi bias merefleksikan komitmen perusahaan terhadap kepuasan pelanggan dan keyakinannya pada tingkat kualitas jasa yang ditawarkan.

\section{b. Benefit-Driven Pricing}

Strategi ini didasarkan pada bagaimana jasa digunakan dan bagaimana jasa memberikan nilai tambah bagi pelanggan. Dalam strategi ini, perusahaan menetapkan harga secara eksplisit atas aspek jasa yang secara langsung memberikan manfaat bagi pelanggan. Hasil yang diharapkan adalah pelanggan akan merasa puas karena berkurangnya persepsi mereka terhadap ketidakpastian bahwa harga jasa yang dibayarkan tidak berkaitan dengan harga jasa yang diterima.

c. Flate-Rate Pricing.

Flate-rate pricing bisa mengurangi ketidakpastian pelanggan melalui kesepakatan atas harga yang dilakukan di awal transaksi. Dalam hal ini, penyedia jasa menanggung risiko atas segala kemungkinan biaya tambahan yang terjadi.

\section{2) Relationship Pricing}

Pada prinsipnya, strategi ini merupakan upaya menarik, mempertahankan, dan meningkatkan relasi dengan para pelanggan. Strategi ini bermanfaat bagi perusahaan maupun bagi pelanggan. Bagi perusahaan, mempertahankan pelanggan jauh lebih murah dibandingkan meraih pelanggan baru. Bagi 
pelanggan, juga diuntungkan karena menjalin hubungan dengan penyedia jasa yang kompeten dan terpercaya. Pendekatan yang bisa digunakan antara lain: (a) Long Term Contracts, di mana pemasar bisa menggunakan kontrak jangka panjang yang memberikan insentif harga dan nonharga kepada pelanggan agar mereka bersedia mengikat diri pada relasi jangka panjang yang saling menguntungkan. (b) Price Bundling, yaitu perusahaan menjual dua atau lebih jasa dalam satu paket, di mana harga paket lebih murah daripada harga total masing-masing item jika dijual terpisah.

3) Efficiency Pricing

Aspek utama dalam strategi ini adalah pemahaman, pengelolaan dan penekanan biaya. Sebagian atau seluruh pneghematan biaya akan diteruskan kepada para pelanggan dalam bentuk harga yang lebih murah. Agar dapat efektif, struktur biaya yang rendah harus sulit ditiru oleh pesaing, minimal dalam jangka pendek. Selain itu, penghematan biaya yang diteruskan kepada konsumen harus dapat meningkatkan persepsi positif konsumen terhadap nilai produk.Sementara itu, Zeithaml \& Britner (2003:318) menguraikan sejumlah persoalan khusus yang berkaitan dengan aplikasi tiga metode penetapan harga konvesional ke dalam sectorjasa,yakni:

\section{a. Cost-Based Pricing}

Metode ini menetapkan harga berdasarkan biaya-biaya finansial. Dalam metode ini, harga diperoleh dengan jalan menghitung biaya penuh untuk menghasilkan dan memasarkan sebuah jasa dan menambahkan imbuhan harga (mark-up).

b. Competition-Based Pricing

Metode ini berfokus pada harga yang ditetapkan oleh perusahaanperusahaan lain dalam pasar yang sama. Metode ini tidak selalu berarti menetapkan harga yang persis sama dengan pesaing, namun bisa pula menggunakan harga pesaing sebagai patokan atau pembanding untuk penetapan harga jasa perusahaan.

c. Demand-Based Pricing (Value-Based Pricing)

Metode ini diorientasikan pada perspektif pelanggan. Metode ini memiliki keunggulan dibandingkan metode-metode lainnya karena memperhitungkan tiga hal, yakni a) pelanggan mengalami kesulitan dalam mendapatkan harga referensi;b) pelanggan bisa sensitif terhadap harga-harga nonmoneter;c) pelanggan menilai kualitas berdasrkan harga. Metode ini menetapkan harga konsisten dengan persepsi pelangganterhadapnilai.

Strategi penetapan harga jasa bisa didasarkan pada persepsi pelanggan terhadap nilai. Secara lebih rinci, alternatif strategi yang tersedia meliputi beberapa hal berikut ini:a) Nilai adalah harga murah.Beberapa strategi penetapan harga yang sesuai untuk definisi nilai adalah sebagai berikut; Discounting, yaitu menawarkan diskon atau potongan harga untuk mengomunikasikan kepada para pembeli yang sensitif terhadap harga bahwa mereka mendapatkan nilai yang diharapakan. Odd 
Pricing, yaitu menetapkan harga jasa sedemikian rupa sehingga membuat konsumen mempersepsikan bahwa mereka mendapatkan harga lebih murah. Caranya adalah dengan menggunakan satuan ganjil tertentu seperti Rp.9750,00 (mendekati Rp.10.000,00). Synchro-Pricing, yaitu menggunakan harga untuk mengelola permintaan akan jasa melalui pemahaman atas sensitivitas pelanggan terhadap harga. Penetration Pricing, yaitu menetapkan harga yang murah untuk jasa baru dengan tujuan mendorong pencobaan produk dan pemakaian lebih luas. b) Nilai adalah segala sesuatu yang saya inginkan dari sebuah jasa.

Strategi penetapan harga jasa yang cocok untuk perspektif ini sebagai berikut: Prestige Pricing, yaitu menetapkan harga mahal untuk jasa prestisius yang berkualitas tinggi. Skimming Pricing, yaitu menetapkan harga mahal untuk jasa-jasa baru yang didukung dana besar untuk promosi.c) Nilai adalah kualitas yang saya dapatkan dari harga yang saya bayarkan.

Strategi-strategi spesifik berdasarkan definisi ini meliputi beberapa hal berikut: Value Pricing, yaitu penetapan harga jasa yang didasarkan pada konsep "giving more for less", di mana sejumlah jasa dikemas dalam satu paket yang memiliki daya tarik bagi berbagai kelompok pelanggan. Market Segmentation Pricing, yaitu menetapkan harga berbeda bagi berbagai segmen pelanggan yang berbeda atas dasar perbedaan persepsi terhadap tingkat kualitasjasa.d) Nilai adalah semua yang saya dapatkan dari semua yang saya berikan. Price Framing, yaitu mengorganisasikan informasi harga bagi pelanggan dalam rangka memberikan harga referensi yang akurat atas jasa perusahaan. Dalam hal ini, pemasar berusaha memberikan harga pembanding yang relevan dengan jasa-jasa lain yang familiar bagi pelanggan. Price Bundling, yaitu menetapkan harga dan menjual berbagai jasa dalam satu paket. Complementary Pricing, yaitu menetapkan harga untuk produk-produk yang sifatnya saling terkait atau komplementer.

Strategi ini terdiri atas tiga bentuk. Pertama, captive pricing, yaitu menetapkan harga murah untuk produk atau jasa pokok yang ditawarkan dan kemudian mengompensasinya pada jasa peripheral yang dibutuhkan untuk mengoptimalkan konsumsi jasa bersangkutan. Kedua, two-part pricing, yaitu merinci harga jasa ke dalam dua bentuk, fixed fee dan variable usage fees. Ketiga, Loss Leadership Pricing, yaitu menurunkan harga jasa yang sangat familiar bagi pelanggan secara signifikan. Tujuannya untuk menarik pelanggan agar datang ke outlet penyedia jasa, kemudian menawarkan pula jasa-jasa lainnya dengan harga yang lebih mahal.Result-Based Pricing, yaitu menetapkan harga berdasarkan hasil jasa, terutama untuk jasa-jasa yang hasilnya sangat penting bagi pelanggan namun tingkat ketidakpastiannya tinggi.

\section{METODE PENELITIAN}

Metode penelitian yang digunakan dalam penelitian ini adalah teknik deskriptif dengan pendekatan kualitatif. Metode kualitatif adalah metode penelitian yang berlandasan pada filsafat post positivisme, digunakan untuk meneliti pada kondisi 
objek yang alamiah, (sebagai awalan lawannya adalah eksperimen)peneliti adalah sebagai instrumen kunci, teknik pengumpulan data dilakukan secara triangulasi (gabungan), analisis data bersifat induktif atau kualitatif, dan hasil penelitian kualitatif lebih menekankan makna dibandingkan generalisasi (Sugiyono, 2012)

Dalam penelitian kualitatif tidak menggunakan istilah populasi, tetapi oleh Spradley dalam buku (Sugiyono, 2012) dinamakan "Social Situation" atau situasi sosial yang terdiri atas tiga elemen yaitu : tempat (place), pelaku (actor), dan aktivitas yang berinteraksi secara sinergis. Dalam penelitian kualitatif tidak menggunakan populasi, karena penelitian kualitatif berangkat dari kasus tertentu yang ada pada situasi sosial tertentu dan hasil kajiannya tidak akan diberlakukan ke populasi, tetapi ditransferkan ke tempat lain pada situasi sosial yang memiliki kesamaan dengan situasi sosial pada kasus yang dipelajari. Sampel dalam peneitian kualitatif bukan dinamakan responden, tetapi sebagai narasumber, atau partisipan, informan, teman dan guru dalam penelitian. Sampel dalam penelitian kualitatif, juga bukan disebut sampel statistic, tetapi sampel teoretis, karena tujuan penelitian kualitatif adalah menghasilkan teori. Dari pengertian tersebut, maka yang menjadi populasi dalam penelitian ini terdapat beberapa situasi sosial dalam penelitian ini yaitu pihak pengguna transportasi online Go-Jek, pengemudi Go-Jek, beserta pesaing transportasi online.

Teknik pengambilan sampel pada penelitian ini adalah purposive sampling dan snowball sampling. Aktivitas dalam analisis data kualitatif ini dilakukan secara interaktif dan berlangsung secara terus-menerus sampai tuntas. Aktivitas dalam analisis data penelitian ini yaitu : data reduction (reduksi data), data display (penyajian data), dan conculsion drawing/verification (penarikan kesimpulan).

\section{HASIL DAN PEMBAHASAN}

Go-Jek merupakan sebuah perusahaan yang berdasarkan hubungan kemitraan antara perusahaan sebagai penyedia layanan aplikasi dan pihak lain sebagai mitra kerja (driver/pengemudi) dengan sistem pembagian hasil sebanyak $80 \%$ untuk mitra dan $20 \%$ untuk perusahaan. Go-Jek menjadi sebuah solusi berbasis teknologi yang memudahkan segala kebutuhan kehidupan sehari-hari masyarakat. Strategi penetapan harga yang dilakukan oleh Gojek menjadi menarik untuk dibahas, terutama jika dikaitkan dengan keputusan konsumen untuk menggunakan jasa ojek online gojek jika dibandingkan dengan jasa ojek online lainnya.

Untuk mengukur produktivitas mitra (driver) PT. Go-Jek Indonesia menggunakan rating (tanda bintang) yang ada pada aplikasi Go-Jek yang diberikan oleh pelanggan setelah menggunakan jasa Go-Jek, setelah itu konsumen juga dapat memberikan komentar pada kolom yang disediakan. Adapun rating (tanda bintang) yang tersedia sebanyak lima buah. Konsumen dapat memberi rating setelah menggunakan jasa Go-Jek mulai dari satu bintang sampai lima bintang sesuai yang dirasakan konsumen setelah menggunakan jasa Go-Jek. Semakin banyak bintang 
yang diberikan, maka layanan yang diberikan drver semakin memuaskan dan begitu pula sebaliknya.Rating dan komentar inilah yang sigunakan oleh perusahaan sebagai alat evaluasi atau perbaikan kekurangan bagi mitra (driver) Go-Jek.

Berikut ini adalah model penelitian yang dikembangkan berdasarkan pendekatan kualitatif

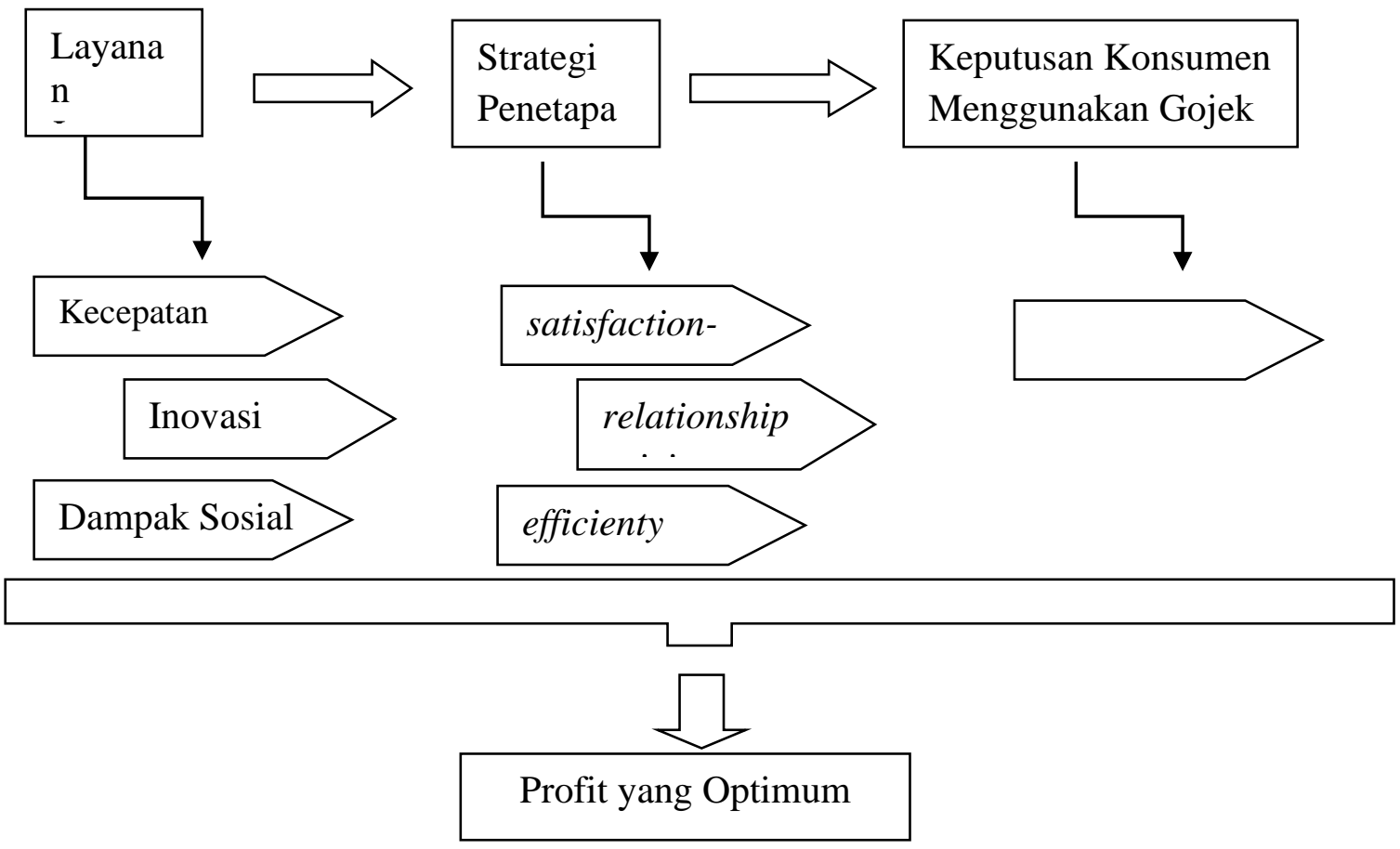

Gambar 3

Model Penelitian

`Model penelitian yang dikembangkan merujuk pada pendekatan kualitatif yang terdiri dari tiga dimensi utama yaitu input, proses dan ouput. Ketiga dimensi tersebut digambarkan sebagai berikut

1. Input

Dimensi input dalam penelitian ini adalah layanan jasa konsumen yang diberikan oleh gojek dengan bertumpu pada tiga nilai pokok yaitu kecepatan, inovasi dan dampak social.

Ketiga nilai pokok tersebut merupakan pilar yang menjadi budaya organisasi gojek dalam memberikan layanan jasa kepada konsumen

2. Proses

Dimensi proses dalam penelitian ini diwakili oleh berbagai strategi penetapan harga yang dilakukan oleh gojek diantaranya melalui tiga aktivitas pricing yaitu satisfaction-based pricing, relationship pricing dan efficienty pricing. 


\section{Output}

Outcome atau hasil akhir dari penelitian ini adalah bagaimana strategi penetapan harga yang dilakukan oleh gojek berdampak pada perilaku konsumen untuk menetapkan gojek sebagai pilihan untuk layanan jasa ojek online dibandingkan dengan jasa ojek online yang lainnya. Dalam jangka panjang keputusan konsumen untuk memilih gojek diharapkan akan mengantarkan gojek pada posisi market leader sehingga dapat menghasilkan profit yang optimum.

Berikut ini merupakan hasil kajian data di lapangan terkait dengan beberapa strategi penetapan harga yang dilakukan oleh gojek untuk menjadi driven bagi keputusan konsumen sehingga mendukung goal perusahaan gojek sebagai market leader dalam pangsa pasar perusahaan ojek online.

Tabel 1

Ringkasan Hasil Penelitian

\begin{tabular}{|c|c|c|c|c|}
\hline $\begin{array}{c}\text { Nilai } \\
\text { Pokok } \\
\text { Perusahaan }\end{array}$ & $\begin{array}{l}\text { Temuan di } \\
\text { Lapangan }\end{array}$ & $\begin{array}{c}\text { Strategi } \\
\text { Penetapan } \\
\text { Harga } \\
\end{array}$ & $\begin{array}{l}\text { Temuan di } \\
\text { Lapangan }\end{array}$ & ndasi \\
\hline Kecep & $\begin{array}{l}\text { Transfer jasa } \\
\text { dan layanan } \\
\text { yang diberikan } \\
\text { gojek kepada } \\
\text { konsumen } \\
\text { terintegrasi } \\
\text { dengan operator } \\
\text { sehingga } \\
\text { kecepatan } \\
\text { informasi bagi } \\
\text { konsumen dan } \\
\text { driver bisa } \\
\text { terkontrol } \\
\text { bersama. }\end{array}$ & $\begin{array}{l}\text { Satisfaction- } \\
\text { based } \\
\text { pricing. }\end{array}$ & $\begin{array}{l}\text { Garansi jasa } \\
\text { yang diberikan } \\
\text { perusahaan } \\
\text { gojek bermuara } \\
\text { pada informasi } \\
\text { yang diberikan } \\
\text { oleh pelanggan, } \\
\text { sehingga } \\
\text { suspend akan } \\
\text { langsung } \\
\text { diberikan } \\
\text { kepada driver } \\
\text { yang tidak bisa } \\
\text { memenuhi } \\
\text { tingkat } \\
\text { kepuasan dari } \\
\text { pelanggan. }\end{array}$ & $\begin{array}{l}\text { Beberapa } \\
\text { pelanggan yang } \\
\text { subjektif cukup } \\
\text { merugikan driver, } \\
\text { karena pihak } \\
\text { manajemen hanya } \\
\text { memperoleh } \\
\text { informasi yang } \\
\text { sepihak. Harusnya } \\
\text { informasi untuk } \\
\text { keputusan suspend } \\
\text { driver diperoleh } \\
\text { dari dua pihak }\end{array}$ \\
\hline Inovasi & $\begin{array}{l}\text { Go-Jek } \\
\text { melaksanakan } \\
\text { tata kelola } \\
\text { struktur } \\
\text { transportasi } \\
\text { yang baik }\end{array}$ & $\begin{array}{l}\text { Relationship } \\
\text { pricing }\end{array}$ & $\begin{array}{l}\text { Price blunding } \\
\text { yang dilakukan } \\
\text { oleh gojek } \\
\text { untuk para } \\
\text { pelanggan yang } \\
\text { menggunakan }\end{array}$ & $\begin{array}{lr}\text { New } & \text { customer } \\
\text { yang } & \text { bukan } \\
\text { merupakan } & \text { target } \\
\text { price } & \text { blunding } \\
\text { lebih } & \text { banyak } \\
\text { tertarik } & \text { pada }\end{array}$ \\
\hline
\end{tabular}




\begin{tabular}{|c|c|c|c|c|}
\hline $\begin{array}{c}\text { Nilai } \\
\text { Pokok } \\
\text { Perusahaan }\end{array}$ & $\begin{array}{l}\text { Temuan di } \\
\text { Lapangan }\end{array}$ & $\begin{array}{c}\text { Strategi } \\
\text { Penetapan } \\
\text { Harga } \\
\end{array}$ & $\begin{array}{l}\text { Temuan di } \\
\text { Lapangan }\end{array}$ & Rekomendasi \\
\hline & $\begin{array}{l}\text { dengan } \\
\text { menggunakan } \\
\text { kemajuan } \\
\text { teknologi } \\
\text { dengan } \\
\text { berbagai fitur } \\
\text { yaitu Go-Send, } \\
\text { Go-Food, Go- } \\
\text { Mart, Go-Car, } \\
\text { Go-Box, Go- } \\
\text { Glam, Go- } \\
\text { Clean, Go- } \\
\text { Massage, Go- } \\
\text { Busway, Go- } \\
\text { Tix, Go-Pay. }\end{array}$ & & $\begin{array}{lr}\text { go bill berupa } \\
\text { tagihan listrik, } \\
\text { PAM, } \\
\text { tagihan } \\
\text { dengan } \\
\text { memberikan } \\
\text { cash } \\
\text { senilai } \quad 50 \quad \% \\
\text { dari } \\
\text { tagihan }\end{array}$ & $\begin{array}{lr}\text { stategi ini di } \\
\text { bandingkan } \\
\text { dengan pelanggan } \\
\text { lama, sehingga ide } \\
\text { ini menjadi tidak } \\
\text { efektif. Harusnya } \\
\text { bisa dibedakan } \\
\text { promosi r untuk } \\
\text { pelanggan lama } \\
\text { dan pelanggan } \\
\text { baru sehingga } \\
\text { sesuai rengan } \\
\text { target relationship } \\
\text { pricing }\end{array}$ \\
\hline $\begin{array}{l}\text { Dampak } \\
\text { Sosial }\end{array}$ & $\begin{array}{l}\text { Go-Jek } \\
\text { mengembangkan } \\
\text { ekonomi } \\
\text { kerakyatan } \\
\text { dengan berfokus } \\
\text { pada } \\
\text { pemberdayaan } \\
\text { para pekerja } \\
\text { sektor informal } \\
\text { sehingga } \\
\text { meningkatkan } \\
\text { penghasilan dan } \\
\text { kesejahteraan }\end{array}$ & $\begin{array}{l}\text { Efficienty } \\
\text { pricing }\end{array}$ & $\begin{array}{l}\text { Demand-Based } \\
\text { Pricing yang di } \\
\text { tetapkan gojek } \\
\text { berdasarkan } \\
\text { tarif Km (Kilo } \\
\text { Meter) } \\
\text { perjalanan yang } \\
\text { ditempuh. } \\
\text { Dengan metode } \\
\text { ini penetapan } \\
\text { harga yang } \\
\text { dilakukan oleh } \\
\text { gojek konsisten } \\
\text { dengan persepsi } \\
\text { pelanggan } \\
\text { terhadap nilai. }\end{array}$ & $\begin{array}{lr}\text { Kilo } & \text { meter } \\
\text { perjalanan } & \text { yang } \\
\text { ditempuh } & \text { oleh } \\
\text { pelanggan menuju } \\
\text { lokasi } \\
\text { menggunakan } \\
\text { aplikasi google } \\
\text { map, dimana rute } \\
\text { yang dipilih } \\
\text { merupakan rute } \\
\text { terjauh dari } \\
\text { beberapa rute yang } \\
\text { laiinya menuju } \\
\text { lokasi, sehingga } \\
\text { harga yang di } \\
\text { tetapkan menjadi } \\
\text { tinggi hal ini } \\
\text { memberikan } \\
\text { keuntungan secara } \\
\text { sepihak terhadap } \\
\text { perusahaan dan } \\
\text { merugikan bagi } \\
\text { para pelanggan. }\end{array}$ \\
\hline
\end{tabular}




\begin{tabular}{|c|c|c|c|c|}
\hline $\begin{array}{c}\text { Nilai } \\
\text { Pokok } \\
\text { Perusahaan }\end{array}$ & $\begin{array}{l}\text { Temuan di } \\
\text { Lapangan }\end{array}$ & $\begin{array}{c}\text { Strategi } \\
\text { Penetapan } \\
\text { Harga } \\
\end{array}$ & $\begin{array}{l}\text { Temuan di } \\
\text { Lapangan }\end{array}$ & Rekomendasi \\
\hline & & & & $\begin{array}{l}\text { Idealnya rute yang } \\
\text { dipilih untuk } \\
\text { menuju lokasi } \\
\text { pada saat } \\
\text { menggunakan } \\
\text { google map adalah } \\
\text { rute terdekat, } \\
\text { sehingga harga per } \\
\text { kilometer yang di } \\
\text { tetapkan menjadi } \\
\text { fair. }\end{array}$ \\
\hline
\end{tabular}

\section{Proses Promosi yang Dilakukan Gojek}

1) Sales promotion

Ada beberapa promosi penjualan jasa ojek yang dilakukan oleh Go-Jek, pada awal kemunculannya, Go-Jek melakukan promosi dengan memberikan voucher gratis sebesar Rp 50.000 kepada semua masyarakat yang mengunduh aplikasinya di google play (Android) atau app store (IOS).

2) Personal Selling

Penjualan personal yang dilakukan oleh Go-Jek seperti menggunakan perantara Sales Promotion Girl (SPG) dipusat perbelanjaan, stasiun, maupun event seperti bazar.SPG yang dipekerjakan oleh Go-Jek bersifat on-project atau hanya dipekerjakan selama ada event tertentu. SPG melakukan flyering(menyebarkan flyer) dan mengarahkan target khalayak untuk mengunduh dan mengikuti akun media sosial Go-Jek. SPG berfungsi sebagai perantara antara Go-Jek dengan calon pelanggan

3) Public Relations

Dalam membangun Public Relation dapat diakatakan bahwa Go-Jek sangat baik dalam penerapan bagian dari promotion mix ini, ini karena Go-Jek telah memilki hubungan yang cukup baik dengan media, ini dibuktikan dengan beberapa media yang memberitakan konflik Go-Jek dengan ojek lokal dan Organda (Organisasi Angkutan Darat) bernilai positif bagiGo-Jek sendiri. itulah beberapa bukti Go-Jek untuk membangun hubungan yang baik dengan konsumennya, sehingga konsumen semkin loyal dengan jasa ditawarkan GoJek.

4) Advertising (Periklanan)

Dalam penerapan Promotion mix khususnya advertising, Go-Jek menggunakan media internet untuk memperkenalkan produknya, sebagai contoh penggunaan 
media youtube, selain media youtube, Go-Jek juga menggunakan media seperti Facebook, Twitter, Instagram serta sebagai sponsor atau media partner dalam suatu event atau acara besar lainnya.

\section{E. SIMPULAN}

Berikut ini simpulan penelitian ini adalah sebagai berikut

1. Strategi penetapan harga yang dilakukan oleh Gojek berorientasi pada konsumen melalui tiga pilar pokok yaitu kecepatan, inovasi dan dampak social. Setiap keputusan dan penetapan harga berorinetasi pada nilai budaya tersebut misalnya dalam strategi efficiency pricing, salah satu metode yang ditetapkan adalah demand based pricing artinya penetapan harga yang dilakukan berdasarkan permintaan konsumen yang konsisten dengan persepsi pelanggan terhadap nilai.

2. Strategi harga yang dilakukan Go Jek adalah dengan memberikan promosi. Kemudian dalam promosi meliputi berbagai metode untuk mengkomunikasikan manfaat jasa kepada pelanggan potensial dan aktual. Terdiri atas periklanan, promosi penjualan, direct marketing, personal selling danpublic relation. Bentuk promosi yang diberikan Go-Jek berupa potongan harga secara langsung, promo pada digital marketing, dan voucher. Penetapan tarif Go-Jek yang relative murah dibandingkan pesaing akan membuat konsumen memutuskan untuk melakukan penggunaan layanan jasa secara berulang-ulang

\section{DAFTAR PUSTAKA}

Alfabeta., S. (. (2012). Metode Penelitian Kuantitatif, Kualitatif, dan R\&D. Bandung: Alfabeta.

Kanuk, S. d. (2004). Perilaku Konsumen Edisi 7. Jakarta: Prentice Hall.

Kotler. (2005). Manajamen Pemasaran Jilid 1 dan 2. Jakarta: PT. Indeks Kelompok Gramedia.

Kotler, P. a. (2009). Prinsip-Prinsip Manajemen Pemasaran (Edisi Indonesia). Jakarta: Erlangga.

Olson, P. d. (2000). Consumer Behavior: Perilaku Konsumen dan Strategi Pemasaran. Jakarta: Erlangga. 
Pranoto. (2008). Pengaruh Harga dan Kualitas Produk Terhadap Keputusan Konsumen Membeli Kendaraan Bermotor. Jurnal Ilmiah Faktor Extra, 1, 6882.

Rahman. (2010). Strategi Dahsyat Marketing Mix. Jakarta: Trans Media.

Setiadi. (2003). Perilaku Konsumen. Jakarta: Kharisma Putra Utama.

Swastha, B. (2009). Manajemen Penjualan. Yogyakarta: BPFE.

Tjiptono. (2014). PemasaranJasa-Prinsip, Penerapan, dan Penelitian. Yogyakarta: Andi Offset. 